\title{
Gendered Geographies of Environmental Injustice
}

Susan Buckingham and Rakibe Kulcur

Centre for Human Geography, Brunel University, Uxbridge, UB8 3PH, UK

susan.buckingham@brunel.ac.uk

rakibe.kulcur@brunel.ac.uk

Published in ANTIPODE 41,4 pp659-683 


\title{
Gendered Geographies of Environmental Injustice
}

\begin{abstract}
$\underline{\text { Abstract }}$
As environmental justice concerns become more widely embedded in environmental organizations and policy making, and increasingly the focus of academic study, the gender dimension dissolves into an exclusive focus on race/ethnicity and class/income. While grass roots campaigning activities were often dominated by women, in the more institutionalized activities of organizations dominated by salaried professionals, gender inequality is neglected as a vector of environmental injustice, and addressing this inequality is not considered a strategy for redress. This paper explores some of the reasons why this may be so, which include a lack of visibility of gendered environmental injustice; professional campaigning organizations which are themselves gender blind; institutions at a range of scales which are still structured by gender (as well as class and race) inequalities; and an intellectual academy which continues to marginalize the study of gender - and women's - inequality. The authors draw on experience of environmental activism, participant observation, and other qualitative research into the gendering of environmental activity, to first explore the constructions of scale to see how this might limit a gender-fair approach to environmental justice. Following this, the practice of 'gender mainstreaming' in environmental organizations and institutions will be examined, demonstrating how this is limited in scope and fails to impact on the gendering of environmental injustice.
\end{abstract}

Key Words: Environmental Justice; Environmental Injustice; Scale; Women; Gender 


\section{Introduction}

Environmental justice has been gaining traction as it evolves from an advocacy practice (which it still is) to both a subject for intellectual research and an analytical approach to environmental inequalities. Moreover, the call for environmental justice has been taken up by a number of environmental organizations, particularly in Europe (see, for example, Friends of the Earth and Greenpeace). While the theoretical and methodological frameworks used by academics trying to understand and explain environmental injustice are varied, they tend to focus on inequalities in income and/or race ${ }^{1}$, while neglecting those of gender. Both the US Environmental Protection Agency's definition ("Environmental justice is the fair treatment for people of all races, cultures and incomes regarding the development of environmental laws, regulations and policies") and that provided by Capacity Global for the UK "as equal access to a clean environment and equal protection from possible environmental harm irrespective of race, income, class or any other differentiating feature of socio-economic status" (Schwarte and Adebowale, 2007:13) focus on race/ethnicity and class/income as defining features of environmental injustice. Its origins in the predominantly African-American rural hazardous waste site protests in the 1980s, which focused on the injustice of environmental negativities being clustered in minority ethnic communities (Bullard, 1999), has focused attention on race and ethnicity as both an explanation for, and mobilizing tool against, environmental injustice at the community level: the geographical scale at which the environmental impact is most strongly perceived. More recently, and particularly in the UK, relative poverty has been acknowledged as a dimension of environmental injustice (Agyeman, 2000; Dunnion and Scandrett, 2003; Friends of the Earth Scotland, 2003; Walker et al, 2005)². However, the relationship between environmental injustice and other forms of social disadvantage delineated by age, disability and gender remains poorly articulated by all but a handful of commentators and activists (although for an exception see the London Sustainability Exchange, 2004). 
We argue in this paper that environmental justice, as a campaign focus, and as an analytical framework (along with other normative theories of poverty, inequality, wellbeing, social injustice and policy reform, on which see Robeyns, 2008), needs to broaden its focus to address a wider range of inequalities than it currently does. Arguing that class has been neglected as a factor structuring environmental injustice, Pellow and Brulle have called for a wider consideration of inequality on the basis that "Scholars cannot understand - and policy makers cannot prevent - environmental injustices through a singularly focused framework that emphasizes one form of inequality to the exclusion of others." They continue to make a case that "environmental injustices affect human beings unequally along the lines of race, gender, class and nation, so an emphasis on any one of these will dilute the explanatory power of any analytical approach." (Pellow and Brulle 2005:298) While it is encouraging to note such a call in a literature largely devoid of references to gender, it has to be noted that it is made in a book in which this is virtually the only mention of gender.

By focusing on gender inequality as a component of environmental injustice we consider the usefulness of concepts of scale and intersectionality as ways of widening consideration of environmental injustice. As Pellow and Brulle have argued, environmental injustice needs to be regarded within the larger "social dynamics of the social production of inequality and environmental degradation." (Pellow and Brulle 2005:3) No society is one dimensionally exclusive: a society which is racist and classist is likely also to be sexist and to marginalise others by age, disability or frailty. It is not enough, then, for any analysis to focus on a limited number of components of environmental injustice without an acknowledgement of wider structures of power and prejudice. Krall's paraphrase of Blatchford on the importance of adopting the perspective of native people as a guide to nature cautions: "Locked in the mentality of politics, they ('persons who have lost touch with Mother Earth') 
seek the greatest good for the greatest, but they should not move until the least is cared for. (Krall 1994:81)

In part, we would argue, this neglect of gender is due to the less publicly visible scales at which the consequences of environmental injustice for women, less geographically concentrated than ethnic minorities or people in poverty are manifested (although, as Bradshaw et al, 2003, identify for the UK, women outnumber men in poor communities): the individual body and the household or family. More combatively, we also suggest that it is the organizational structures of the campaigning groups, mobilizing around environmental and environmental justice issues, which contribute to this neglect. Large environmental NGOs, increasingly drawn into advising and lobbying institutions on environmental matters, including environmental justice, together with the institutions themselves, draw the contours of what does, and does not, constitute environmental injustice (see also Brulle and Essoka, 2005). While organizations combating environmental injustice deserve praise and support for raising racism, as well as low income, as factors determining unfairly distributed environmental benefits and problems, we argue that they now need to widen their concerns to embrace other forms of inequality if real environmental justice has a hope of being achieved. Our focus in this paper, based on our own research and environmental activism, is gender. We argue this on the basis that a particularly powerful alignment of factors conspires to marginalize gender: lack of visibility of environmental gender injustice; campaigning organizations which are themselves gender blind at best, masculinist, at worst; institutions at a range of scales which are still structured by gender (as well as class and race) inequalities, and an intellectual academy which continues to marginalize the study of gender - and women's - inequality. 
The paper will first argue that the lack of a gender perspective in most of the environment injustice literature limits both the analyses themselves as well as opportunities for improving environmental justice for other groups. Following this, constructions of scale are explored to see how these might constrain a gender-fair approach to environmental justice. Using an example of waste management to illustrate how gendered institutional structures, and a failure to interrogate inequality within the household, compound environmental injustice, the paper will examine the success or otherwise of "gender mainstreaming" policies, against a background of continued gender inequalities in environmental organizations and other institutions.

\section{Women and the Environmental Justice Literature}

Analyses of environmental injustice have tended to revolve around the nature of justice (Schlosberg, 2007; Walker and Bulkeley, 2006), the contours of environmental justice and injustice, both generally and through case studies (Agyeman, 2005; Checker, 2005; Pellow and Brulle, 2005; Pulido, 1996) and its tendency to exclude broader issues of sustainability (Agyeman, Bullard and Evans, 2003). Leaving aside the few explicitly focused articles on gender and environmental justice such as those by Kurtz (2007), Nightingale (2006) and Sze $(2004,2006)$, and, often tokenistic, chapters in books on environmental injustice which elsewhere fail to engage with gender, these analyses, as the movements themselves, have mostly ignored the "gender question". Key recent books on environmental justice have conspicuously failed to develop an analysis which includes women and gender, while at the same time raising issues which ecological feminist arguments could illuminate. For example, Schlosberg (2007) argues that environmental injustice analyses fail to acknowledge ecological justice, although this link has been made by ecofeminists seeking to develop an ethic of care, which embraces non-human as well as human life. (Merchant, 1996, 2005: and see Plumwood for a "realign[ment of] reason... with social formations built on radical democracy, co-operation and mutuality". (Plumwood 1993:196). 
Taylor's claim that environmental justice is "the first paradigm to link environment and race, class, gender, and social justice concerns in an explicit framework" (Taylor, 2000:542) likewise neglects the work done by ecofeminists in the past, although this is belied by her earlier, innovative, contribution on women, race and environmental justice to Karen Warren's collection of writings on ecofeminism (1997). Nor is her claim borne out by analyses of environmental injustice, despite the majority of grass roots protest being generated by women, and in the USA, mostly women from low income communities, and women of colour (Di Chiro, 1998). That theories of environmental justice have generally failed to take gender into account is not surprising. According to Robeyns, "most justice theories do not make their account of gender relations explicit and do not respond to feminist critiques, but are implicitly relying on androcentric and gender-biased assumptions". (Robeyns 2008: 89) However, the dialogue between eco-socialists and ecofeminists, which has addressed the nexus between class and gender through structural causes of inequality concerning socio-environmental relationships, suggests scope for this engagement to be taken up by those investigating environmental injustice (see Godfrey; Goldstein; Salleh; Turner and Brownhill, all in a special issue of Capital, Nature, Socialism, 2006).

There are a number of reasons which may explain this hitherto missed opportunity. For example, MacGregor (2006) argues that ecofeminism's focus on care and the private realm reduces its potency for an environmental justice grounded in citizenship and public space, while a number of writers have observed a machismo prevalent in the environmental movement which works against women, and women's interests (MacGregor, 2006; Salleh, 2008; Seager, 1993). Shrader-Frechette has also noted sexism (as well as racism) in the media, which she believes fails to give voice to the grass roots environmental justice movement because it is "led largely by women of color" (Shrader-Frechette 2002: 13). This highlights the importance of considering intersectionality, through which the overlap between vectors of disadvantage is revealed more clearly. 
MacGregor (2006) makes a powerful challenge to what she sees as the reification of care work as women's, although we would argue that women's continuing prominence in both low paid and unpaid caring demands that it be a consideration of policy as well as campaigning. A good example of this can be found in McDowell's work on an "ethic of care" in which she invokes the "relational view of self", arguing that it is "undeniable that there are clear associations between gender, caring and philosophical attitudes based on common practices and responsibilities" (McDowell 2004:156), which are not well rewarded in contemporary, neo-liberal society. Likewise, Robeyns (2008), in critiquing social theories of wellbeing and justice from a capabilities perspective ${ }^{3}$, argues that these frequently neglect the, often invisible, care responsibilities undertaken by women. It is also useful to consider the work of Iris Marion Young in this context, whose arguments concerning the importance of procedural justice have influenced some writing on environmental justice (for example, Schlosberg, 2007, and see later in this paper). What these writers have not taken up, however, is Young's analysis of the division of labour as an institutional practice, which has a bearing on justice. In particular she considers the exploitation of women in the home and in the workplace, through their provision of care, a point this paper will take up later.

Feminist discussion of "intersectionality", which "locates gender within contexts of race, ethnicity, class and citizenship among other socially constructed categories that interact to shape women's lives and social identities" (Lee, 2007:2; and see Cuomo, 1994), also offers environmental justice analyses a potentially useful way into considering gender. Carolyn Merchant $(1996,2005)$ reworked her own earlier positions on ecofeminism in favour of what she has called a "partnership ethic", which "...treats humans (including male partners and female partners) as equals in personal, household and political 
relations and humans as equal partners with (rather than controlled by or dominant over) nonhuman nature". (Merchant, 2005:196)

\section{Scale}

Through increasingly nuanced understandings of the concept of scale (Marston, 2000), it is apparent that scales are both relational, and imbricated in complex ways, as well as being structured by internal and external politics of scale (Brenner, 2001). What manifests locally, within the household, or even on the body, is as likely as not to have its genesis at the wider scales, which more commonly come under the purview of economists, political scientists, and mainstream geographers.

It has been argued elsewhere that environmental injustices specifically affecting women often operate at scales which seem invisible to those not actively studying and searching for them (Buckingham, 2006, 2007). This is illustrated by Brenner arguing that the household has only an "internal politics of scale", rendering it indistinguishable from a "place" or a "locale" (Brenner 2001:596). This fails to recognise cross scale politics which tie the household with various levels of governance, political decisions and business practice, and illustrates the invisibility of the domestic scale to many academics. One need only consider the burden placed on households to adopt environmental strategies such as recycling or energy efficiency to "save the planet" - actions which normally fall to women in the household (Buckingham et al, 2005; Defra, 2002; MacGregor, 2006; WDR, 2008) - or the enthusiasm business has shown for flexible working at home to offset its own operational costs, to recognize how the household is deeply entwined with other scales.

Marston and Smith, in their rejoinder to Brenner, argue that the "scale of the household (and the home) is integral to [scaled social] process[es]" (Marston and Smith 2001:616). A case they also make for 
considering the body as a valid scale. Mostly, however, the argument that the household and the body are as valid as any other scale is made by feminist geographers such as Linda McDowell (1999). Young proposes that feminist movements were in the "vanguard" of insurgency movements, which began as collectives designed as much to empower women as to politicize them. Such insurgency movements, she writes, exploit and expand the space between individuals and families on the one hand, and states and large corporations on the other (Young 1990:82-85), points illustrated by the relatively rare accounts of gendered resistance to environmental injustice (see for example, Gibbs, 1996; Kurtz, 2007; Sze 2004).

\section{The Body}

Another argument for environmental justice activists and commentators to broaden their conceptual framework to include a gender analysis is the feminist critique of society "othering" the female as a variant of the "normal" male. This questions the validity of testing chemicals and pharmaceuticals on fit male bodies, when it is known that women's bodies (and children's, the elderly, frail and other groups similarly constituted as 'different') will experience these products in different ways (EEA, 2003).

A point conceded by the European Union, though not entirely dealt with through in its $\mathrm{REACH}^{4}$ legislation, is that pregnant and nursing women, as well as women who plan to bear children in the future, are particularly vulnerable to environmental pollution. This links to environmental justice in that as well as combating pollution at source, or campaigning for this to be redistributed more fairly, or redistributed away from those most at risk (which may well result in a very different distribution of polluting industries), there should be a much more fundamental argument for challenging any substance release that cannot be proved to be harmless to the most vulnerable. At present, as long as a substance can be expected not to harm the most robust, who, by definition, are the ones tested on, it 
is deemed acceptable. Although this precautionary approach to environmental pollution is technically recognized by a number of international organizations (for example, through European Union law), it is a long way from thorough implementation.

Sze (2006), uses the example of DES (diethylstilbestrol - an artificial oestrogen prescribed to women in the 1940s and 1950s to prevent miscarriages, treat menopause, and other hormonal "problems", as well as to fatten up livestock) to illustrate the gendered nature of its ultimate ban. Although its carcinogenic effect on females generated a challenge to the US Federal Drug Administration by the women's health movement, Sze explains that a ban was only applied once the unnatural - that is feminised - "sexual and bodily development" was noted in men who had eaten DES fed poultry (Sze, 2006: 806). The less visible, though obviously harmful, impacts on women were not similarly acted upon "until there was a greater body of scientific evidence" (Sze 2006:797). Such readings, she argues, have led to an emerging recent literature of environmental injustice arising from literary and cultural studies, to culturally redefine "the environmental to mean...human bodies, especially in racialized communities, in cities, and through labor" (Sze 2006:792).

Most ecofeminist analyses argue that masculine identity "depends on men distancing themselves from the fact [of being part of nature]". (Salleh,1997:13). This is not to argue that women are essentially, qua women, closer to nature, but are confronted with nature more frequently and directly by the unpaid and low paid work they do. Similarly, we would argue that, as with the social model of disability (Shakespeare and Watson, 2002), it is the continued structuring of females as "different" to a male norm which results in a biological manifestation of a socio-environmental problem. One example is that of dioxins which bio-accumulate and which dissolve in fats, making them particularly pernicious chemicals for women who have a greater body fat ratio than men, and who pass on the chemical load 
to fetuses and babies through the placenta and breast milk (Physicians for Social Responsibility, 2001). That this different experience registers biologically, however, does not equate with it being essentialising.

Another example of women's bodies being more vulnerable than men's can be seen from excess mortality related to heat waves. Data for the French heat wave in 2003 shows 75 per cent higher mortality rate for women than for men, which cannot be explained soley by women's greater longevity (Fouillet, et al, 2006). Likewise, in London in 1995, mortality was more noticeable amongst women (23.3\% excess deaths compared to $8.3 \%$ excess deaths for men). There is no simple explanation for this, but Rooney et al (1998) suggest a combination of poverty, deprivation, and vulnerability to associated air pollution. Other reasons advanced included the vulnerability of living alone (Fouillet et al, 2006) and the increased difficulty that women over 60 have in regulating their internal temperature (Kaciuba-Uscilko and Grucza, 2001 in Laadi, et al, 2006). These data suggest that global warming will have a disproportionate effect on women, compared to men in any one community, as extreme weather episodes become more frequent, although this is not a consequence discussed in climate justice discourse.

\section{The Domestic Scale}

Social relations within the home (as a site for reproduction and recreation as well as, increasingly, paid work) are also neglected in many environmental justice analyses. Turner and Brownhill, (2006:92) describe wives and children undertaking unwaged caring and domestic work as "shadow workers", reflecting the relegation of unpaid work in the private sphere. They argue that these workers have a distinct relationship with the environment as a result of their unequal position: 
"...the shadow worker reproduces not only labour power but also to some degree both the natural and built environments. Secondly, while the proletarian's wage entails a degree of power over both the commodity nexus and the shadow labour of his wife and kin, the shadow worker to a much larger degree depends on access to non-commodified or public goods both for subsistence and for expanding her autonomy from wage-earning kin (and capital). Thirdly...the ideological construction of those identity groups assigned to shadow work is deeply linked to constructions of nature." (Turner and Brownhill 2006:9)

Turner and Brownhill, further, warn against a failure to acknowledge the full range of ways in which these shadow workers are marginalized, one result of which is a failure to fully appreciate the nature of environmental injustice. While the home-as-workplace is technically covered by health and safety workplace legislation, which requires monitoring by employers (HSE, 2006), the home remains a largely unsupervised and potentially more hazardous space. It is here where much female labour (unregulated and unpaid as in housework and care of dependents; unregulated and low paid in the case of domestic workers) takes place. Despite the proportion of women in paid work increasing, the majority of unpaid caring and daily household chores continue to be undertaken by women (UNDP, 2007). Robeyns (2008) also points to the unequal distribution of work in the household, which, she argues, has a significant impact on the relative capabilities of household members. It is remarkable that data from North America and Europe reveals that the cooking, cleaning, provisioning, food growing, waste disposal, caring for the sick, frail, young and otherwise dependent, continues to be mostly done by women, despite the steadily increasing presence of women in the paid workforce (UNDP, 2007). This brings women into direct contact with polluting activities, and necessitates a navigation between the needs and health of the cared for, economics, time, and environmental considerations. Although poor communities are more exposed to environmental problems relative to richer communities, within 
any given community, it tends to be women who experience environmental problems disproportionate to their poverty alone.

Sze (2004) draws attention to the way in which disease is gendered in that caring for sick family members tends to fall to the mother in the household, and that judgment on the causes of disease sometimes brings into question the quality of this caring and mothering. Her analysis highlighted the intersectionality of race and gender in an environmental justice campaign against asthma related pollutants. Asthma disproportionately affects low income minority - particularly African American children in urban areas in the United States (as elsewhere), and has been rising sharply. Sze summarised scientific medical evidence which points to both indoor and outdoor pollution as being causes of asthma, but she particularly focuses on the way in which, while government health authorities and corporations claimed "no scientific proof" linking polluting facilities with asthma, the government "Healthy Homes" programme was designed to inspect "usually poor households with asthmatic children". Sze argues that this implication that "poor women or women of color have bad housekeeping practices" and that mothers are to blame for their children's asthma, takes the responsibility away from corporations, inadequate government regulations or systemic failures. (Sze, 2004: 188) Indeed, it is an irony that the women's campaign to reduce pollution at source resulted in the authorities reflecting back this concern as an (the mothers') inadequacy.

Daily housework and caring responsibilities are being augmented by demands that governments are placing on households to, for example, recycle, which, since these practices are mostly undertaken by women (Buckingham et al 2005; Defra 2002, MacGregor, 2006), adds to their "care burden". In the West, environmental considerations might include whether to buy organically certified food and biodegradable cleaning products, whether to compost organic waste and recycle others, whether to 
use reusable nappies, menstrual products and cleaning cloths or to opt for disposable alternatives. Environmentally related campaigns such as "slow food" and "zero waste" are laudable, but it must be recognized that until there is a fair and equitable division of labour in the home, the majority of the burden of this transition will fall to women. As MacGregor has pointed out "with the rise of public campaigns for environmental awareness, those who manage households...are expected to be more diligent in adopting time consuming green practices like recycling and precycling". (2006: 69) This is a wider conception of "environmental injustice" than has hitherto been used, and in the spirit of "gender mainstreaming" it should be incumbent on government departments and environmental campaigning groups to calculate the gender impact of their campaigns - or, even, better, to urge their members to "share the housework". For an example of how this could emerge see Merchant's (2005) work on "partnership ethics". To date, however, there has been what MacGregor describes as a "failure of masculinist environmentalisms to address the gendering of experience and responsibility in the domestic sphere" (MacGregor 2006:61).

UK "nappy politics" illustrates the relationship between inequalities in the division of labour and environmental considerations, as well as the way in which the domestic scale is imbricated with the national. Although disposable nappies constitute approximately $3 \%$ of the UK waste stream and thereby pose an environmental problem, new mothers are targeted by manufactures who distribute a "bounty pack" through the British National Health Service (NHS) containing disposable nappies and toiletries using artificial chemicals (against the NHS's own advice that only water should be used on a baby's skin until she or he is 6 months old, WEN, 2008). New mothers are a vulnerable and impressionable "market" in their anxiety to be "good" mothers, a point which manufacturers of disposable nappies exploit in their advertising and marketing campaigns. On the other hand, these women are urged by women's environmental and health campaigning groups to consider the links 
between their children's and their environment's well being, and adopt the use of reusable nappies. This conflict was aggravated in 2005, when the Environment Agency released its life cycle analysis of reusable and disposable nappies, which alleged that disposable nappies were not more harmful to the environment than reusable nappies, influencing new parents' purchasing decisions and local authority policy. This life cycle analysis is generally thought to have been flawed (see for example, Hickman, 2005; RNA, 2005; WEN, 2008) both on the assumptions made by the study ${ }^{5}$, and the sampling frame (2,000 parents using disposable nappies, 117 parents using reusable nappies, Environment Agency, 2005).

Like the slow food and zero waste movements identified earlier, the real nappy campaign, while empowering mothers to make well informed decisions on the one hand (WEN, 2008), increases the burden of household and caring work from both a physical and an emotional perspective. Consumer empowerment is double edged: women, who increasingly make household purchasing decisions (OECD, 2008), become the battleground of emotionally laden consumer campaigns by both product manufacturers and environmental campaigners. In the absence of a fair division of domestic and caring labour, this produces a particular kind of environmental injustice in which environmental benefit is accrued at the expense of women's time and physical and emotional labour. Social injustice at the household scale (the division - or as Sen (2001) puts it - the accumulation of labour) needs to be factored into environmental justice considerations.

The relationality of scale, which emerges from this consideration of the body and the household, challenges the marginalization of "women's interests" as "inward" or the "politics of the personal" (Marston and Smith, 2001; Salleh 1997:11). Brennen's questioning of the household as a valid scale a "singular politics of scale" (Brennen 2001:599) - denies household boundaries the porosity allowed to 
other scales. In contrast, Krall explains the porosity of the boundary of micro-scales, particularly visible in the female body which "bears life" and food (Krall 1994: 235). She also argues for better recognition of the boundary or "border spaces between the public and private realms" which enable those who inhabit these spaces (arguably more often women) to "provide a pragmatic, moral critique of both" (Krall 1994:236).

\section{Gendering of Institutions and Organisations}

While the distributional aspects of environmental justice focus on the unfair allocation of environmental problems and benefits, procedural aspects concern access to decision making processes which govern these distributions. According to Young, "issues of the just organization of government institutions and just methods of political decision making rarely get raised" and inequalities are reinforced by decision making structures which operate "to reproduce distributive inequality" (Young 1990:22-23). Gender inequalities in governing bodies have long been observed, and it has been noted that this has an impact on the nature of decisions made (Bhattar, 2001; Buckingham, 2005; Equality and Human Rights Commission, 2008; Sealy and Singh, 2008). This persistent inequality has led to the establishment of the Global Gender and Climate Alliance, set up jointly by the United Nations, the IUCN (International Union for Conservation of Nature) and WEDO (Women, Environment and Development Organization), to try to raise the profile of gender issues in climate change policy making (Aguilar, 2009). Less attention, however, has been paid to professional environmental and environmental justice campaigning organizations, which often appear to demographically mirror the employment profiles of the businesses and institutions they challenge. Through Chopra and Duraippah's account of the recent institutionalization of organizations such as WWF, they question the ability of organizations able to institutionalize to break free of prevailing social norms and structures (Chopra and Duraippah 2008:368). 
Gender mainstreaming ${ }^{6}$ has been an attempt to draw more women into decision making, though its impact has been limited. For example, The Environment Agency, referred to above, is not an organization that has embraced gender mainstreaming - a practice statutorily required by European Law (CEC, 1998) - as an interview with their equal opportunities officer pointed out.

Gender mainstreaming has been incorporated into international environmental legislation since 1995 (Morrow, 2006), to ensure that institutional decisions do not have a disproportionately negative effect on one gender (usually taken to mean women and girls), and to draw more women into representative and effective decision making (see European Commission, 1999; George, 2007; Morrow, 2006; United Nations, 2005; World Bank, 2002; and later in this paper). While, technically, environmental decision making in the European Union is subject to gender mainstreaming, these policies are insufficient to ensure gender justice with regard to the environment, or decision making more generally. This is emphasized by research into gender mainstreaming European municipal waste management in the EU (Buckingham et al, 2005), which found that the ways in which municipal waste management was organized and gendered made a difference to waste strategies adopted, and, ultimately, the amount of waste disposed of. Four municipal waste authorities in the UK, Ireland and Portugal were examined in depth to find out how gender was being incorporated in their waste management strategies, and the scope for doing so. The importance of institutional actors was clearly identified with authorities employing women from diverse backgrounds (including education and marketing) to lead on recycling having a much stronger recycling performance than authorities in which waste management remained in control of older men from an engineering background. Their preferred strategies were high technology developments such as incineration, themselves the source of local protests - often dominated by women - against environmental injustice. Municipalities performing more strongly on 
recycling were also more likely to have better and more structured representation of women through public participation (Buckingham et al 2005). Elsewhere, evidence suggests that while men favour technology in environmental problem solving, women tend to prioritise "soft" strategies such as changing lifestyles and consumption patterns which, conventionally, are given less prominence and significantly less financing (Johnsson-Latham, 2007). In some ways, this is an unresolved contradiction, given the disproportionate impact these strategies have on women as the main, unpaid, domestic and care workers, discussed earlier.

Conversely, Johnsson-Latham noted positive impacts where institutions have linked gender with their environmental work, particularly through initiatives set up by women, such as the Network of Women Ministers of the Environment (NWME,) established in 2002 to promote women's participation in environmental policies and to enhance a gender perspective in national and international environmental decision making. Given that environmental justice campaigning seeks to influence policy, and becomes increasingly adopted by formal structures of government (see for example, the GLA, 2004), the gendered nature of policy making is important as it is likely to have a bearing on decisions and action taken.

\section{Environmental Non-Governmental Organisations}

Since environmental non-governmental organizations (hereafter ENGOs) are increasingly drawn into policy making circles through a process Carter (2001) describes as "institutionalization", it is appropriate to examine the degree to which they reflect, in staffing and organizational terms, the organizations they are working with (and see also Chopra and Duraippah, 2008). The ENGOs being called on as a resource for decision making at national and international scales are generally those which are best able to dedicate time, staff and facilities to these activities. This contribution to 
governance is partial and inequitably drawn from the ENGO sector, which has implications for campaigns and strategies developed, and decisions taken. According to Salleh (2008), most NGO campaigning and policy formulation is conducted within masculinist neoliberal terms of reference.

Even if smaller, women-focused, organizations were called as expert witnesses (and one of this paper's author's experience of trusteeship with a leading national women's environmental organization suggests that they are frequently overlooked), they are unlikely to have the resources to enable them to participate in activities, for which there is no financial recompense. The Women's Resource Centre has recently drawn attention to data which demonstrates that charities specifically working on behalf of women are disadvantaged relative to other charities, with women's organizations comprising $7 \%$ of all voluntary organizations in the UK but receiving only $1.2 \%$ of government funding to charities, and even less from independent funders (WRC, 2006). Since environmental charities receive relatively small charitable donations, with New Philanthropy Capital (2008) reporting that the hundred largest charitable trusts donate just $2 \%$ to environmental causes, this bodes particularly ill for women's environmental campaigning. While the organizations discussed below are not exclusively focused on environmental justice, it is increasingly the case in the UK that environmental NGOs use environmental justice as a campaigning hook, and, by virtue of their consultative status, they are powerful determinants of whether or which environmental justice issues are taken up in popular policy discourse.

Of the eight representative European families of sectoral NGO groupings that formed the EU Civil Contact Group in 2008, a prerequisite of which is to be committed to equal opportunities, only two were headed by women (one was the European Women's Lobby, which was the only grouping to have a majority of members women). All of the chief executive officers of organizations comprising the environmental sectoral grouping advising the European Commission - the 'Green Ten' were men (see 
Table 1). This is not to necessarily imply that these groups do not take women, or gender, into account (gender does, in fact, feature on Friends of the Earth Europe's web site as a campaigning issue under environmental justice), but, as with analyses of women's representation on government bodies, the boards of multi national companies and other major employers with significant impact on people's everyday lives, it suggests underlying influences which favour the hiring of men to senior positions, and which may well have an impact on strategies, campaigns and advice given (Equality and Human Rights Commission, 2008). A similar profile can be noted in the largest British ENGOs (see Table 2, and Kulcur, 2008), only two of which have women chairs, and one a woman chief executive officer. With the exception of Greenpeace, the boards are heavily dominated by men (from $63 \%$ to $88 \%$ ).

This understanding of a balance of power in favour of men is reinforced by a survey undertaken by the UK Directory of Social Change, which asked the question: "Do women control the voluntary sector?" Despite $68 \%$ of the voluntary sector workforce being women (which incidentally throws the male domination of senior posts in ENGOs into even sharper relief), and $54 \%$ of volunteers, "overwhelmingly the respondents felt that key decisions remain the province of males". (DSC, 2006).

Table 1: Gendering of ENGOs representing the Green Ten, advising the EU 


\begin{tabular}{|l|l|l|l|}
\hline Organisation & $\begin{array}{l}\text { Chair of } \\
\text { Governing } \\
\text { Board }\end{array}$ & $\%$ Board Male & CEO \\
\hline $\begin{array}{l}\text { European Environmental } \\
\text { Bureau }\end{array}$ & Male (president) & $57 \%$ & Male \\
\hline $\begin{array}{l}\text { Birdlife International } \\
\text { European Community Office }\end{array}$ & Male & $74 \%$ & Male \\
\hline $\begin{array}{l}\text { Climate Action Network } \\
\text { Europe }\end{array}$ & Male & $63.5 \%$ & Male \\
\hline $\begin{array}{l}\text { European Federation for } \\
\text { Transport and Environment }\end{array}$ & Male & $63.5 \%$ & Male \\
\hline \begin{tabular}{l} 
Friends of the Earth Europe \\
\hline Friends of Nature
\end{tabular} & Male & $60 \%$ & Male \\
\hline $\begin{array}{l}\text { Greenpeace European Unit } \\
\text { (International) }\end{array}$ & $\begin{array}{l}\text { Female } \\
\text { (international) }\end{array}$ & $66 \%$ & Male \\
\hline $\begin{array}{l}\text { WWF European Policy } \\
\text { Office }\end{array}$ & Male & $61 \%$ & Male \\
\hline $\begin{array}{l}\text { Health and Environment } \\
\text { Alliance }\end{array}$ & Female & $29 \%$ & Male \\
\hline CEE Bankwatch Network & - -no info & -- & Male \\
\hline
\end{tabular}

Sources: European Commission, 2007; European Environmental Bureau 2008; Birdlife, 2008; Climnet, 2008; Transportenvironment, 2008; Friends of the Earth, Europe, 2006; 2008; WWF, 2008; World Wildlife, 2008; Greenpeace, 2008; Health and Environment Alliance, 2008;

Bankwatch, 2008; Friends of Nature, 2008

\section{Table 2: Gendering of Largest British Environmental NGOs}




\begin{tabular}{|l|l|l|l|}
\hline $\begin{array}{l}\text { Organisation (number of } \\
\text { employees) }\end{array}$ & $\begin{array}{l}\text { Chair of Governing } \\
\text { Board }\end{array}$ & $\begin{array}{l}\text { \%oard } \\
\text { Male }\end{array}$ & $\begin{array}{l}\text { Chief Executive } \\
\text { Officer }\end{array}$ \\
\hline $\begin{array}{l}\text { Royal Society for the Protection } \\
\text { of Birds (1300) }\end{array}$ & Male & $88 \%$ & Male \\
\hline WWF UK (295) & Male & $78 \%$ & Male \\
\hline Carbon Trust (151) & Male & $70 \%$ & Male \\
\hline Greenpeace UK (117) & Female & $42 \%$ & Male \\
\hline Friends of the Earth England (99) & Male & $62 \%$ & Male \\
\hline National Trust (84) & Male & $82 \%$ & Female \\
\hline
\end{tabular}

Source: Kulcur, 2008 (and Annual Reports 2008; RSPB, 2007)

Fincher draws attention to the ways in which the state is shaped by ways in which it is contested by activitist organizations; the ways in which these activist organizations are spatialised and gendered is important to this. Organizations outside the state "help form the actions of the state, shift its practices and alter its interpretations" by "interacting with actors in state bureaucracies in diverse and interesting ways" (Mountz 2003:18 in Fincher, 2007). Fincher argues that it might be useful to "pay more attention to the ways institutions are shaped by their members" interactions with groups and individuals from "outside" their bureaucratic borders.' (Fincher 2006:13.) This is increasingly salient in the environmental sphere, where, as discussed above, campaigning groups, which are demonstrably dominated by men in senior management and governance positions, are increasingly being incorporated by governments, to develop environmental strategies. Analysis of a key resource for campaigning organizations, the Worldwatch Institute, has revealed its signal failure to consider gender as an issue in consumption 
issues (Johnsson-Latham, 2007). Similarly, Lina Sommestad, Minister for the Environment in Sweden between 2002 and 2006, reported a male colleague's response to an initiative on women and the environment as hostile: "What is this? I cannot see why environment has anything at all to do with women" (Sommestad, 2007). This attitude has also been exposed in interviews of ENGOS in the UK in which senior managers failed to see the relevance of gender sensitive campaigns (Kulcur, 2008), and for the European waste management research cited earlier, with ENGOs demonstrating a singular lack of awareness of what a gender analysis could offer. When the director of one of the leading environmental organizations for Portugal was asked about women's involvement in waste campaigns, his response was:

"taking in consideration our lack of time and resources, and the priorities that are in that line, I sincerely think (and this is a personal opinion...) that [including women] is not a priority issue regarding waste." (in Buckingham et al, 2004)

NGOs can "become sites reinforcing the status quo because of their inaction", and consequently cannot be assumed to be "progressive space for social, political and economic activities" (Ruwanpura 2007:318). She found in her work in Sri Lanka that NGOs often worked within the cultural constraints of bureaucracies and institutions, thereby ignoring gender inequalities/atrocities, construed as "culturally acceptable (Ruwanpura 2007:325). The evidence presented above suggests that her argument, that neglecting an analysis of how NGOs integrate (or otherwise) political strategy, power and feminism into an analysis of civil society and how this affects the "structural exclusion of women" (Ruwanpura 2007:327), is relevant for environmental NGOs working in Europe and the USA. Examining the gendered attitudes of mainstream ENGOS to environmental justice is, we would argue, critically important, given their influence in public discourse. For example, Shrader-Frechette (2006) argues that more mainstream groups in the USA, such as the Sierra Club, have failed to support environmental 
justice campaigns because their own structures mirror those in society at large. Such a failure is influential in whether and how environmental justice is taken up by government and other institutions.

Brulle and Essoka (2005) cite Rios's research into the environmental justice movement itself which she found to be more like conventional social movements, with institutional structures and NGO funding. This distanced decision making from its grass roots membership which, as earlier citations have already demonstrated, are often dominated by women, and especially women of colour (Di Chiro, 1998; Sze, 2004; Taylor, 1997). Brulle's own research found environmental justice organizations to have lower levels of democracy than some mainstream environmental groups, whose governance structures they shared (Brulle and Essoka, 2005: 211-215). Brulle and Essoka call for a "broad based effort" to "ensure the organizations of this movement are authentic representations of the communities in which they are based." (Brulle and Essoka 2005:217) Agyeman's work with environmental justice campaigning groups in Boston discusses the difference in staffing, with the community organizers reflecting the ethnic diversity of the neighbourhoods in which they are working, while the office staff are more likely to be white and college educated (Agyeman 2005: 142). What goes less remarked in his analysis is the gender balance, with men more likely to dominate in the office. A quote from a campaign group member concerning the perceived "inauthenticity" of a black woman who was a "Berkeley trained lawyer" and "dating white guys" (Agyeman 2005:142), says as much about gender relations in the organization as it does about race. These analyses of power in organizations campaigning against environmental injustice are particularly important in view of the dominance of grass roots activity originating with women (Schrader-Frechette, 2002; Taylor, 2000). As Cheng suggests, a possible transformation can only be assessed if the organization as a whole is examined (Cheng, 1996: viii). 
Arguably civil society organizations such as the Women's Environment and Development Organization (WEDO), Women in Europe for a Common Future, ENERGIA, LIFE, the Gender and Water Alliance, Women Organizing for Change in Agriculture and Natural Resource Management (WOCAN), and WEN (Women's Environmental Network), all play important, but in light of the foregoing discussions, limited, roles in bringing a gender perspective to the political arena which can have an impact on environmental justice.

\section{Conclusions: Gender Sensitive ways forward for Environmental Justice}

Both the environmental justice movement and ecofeminism have drawn attention to the way in which the traditional environmental movement has tended to assume that environmental damage impacts on people universally. While environmental justice campaigning has clearly revealed this as a fallacy, organizations lobbying for environmental justice generally fail to investigate how environmental racism might itself be fractured by gender and other variables, even though much of the grass roots campaigning in the USA is undertaken by women, often primarily concerned about environmental health issues (Sze, 2004). Indeed, women fighting for environmental justice in the USA in African American, and other disadvantaged communities have been vilified on the basis of their sex (see Gibbs, 1996 and Kurtz, 2007), and their gender roles (Sze, 2004). The sexist language used in challenges to women's claims for environmental justice can also become personalized. Kurtz, for example, quotes ways in which state officials publicly denigrated the protest group she was researching as "a bunch of gray-haired ladies" and "hysterical housewives"...thereby "construct[ing] women activists not only as external to the public sphere, but also as people unconstrained by the rationality of public sphere identification and behaviour..." (Kurtz 2007:9). Kurtz draws parallels with the criticisms leveled at Lois Gibbs when she organized the fight against Love Canal in the 1970s, which perjoratively accused her of presenting "housewives' data". 
As with many political movements fought in the name of "liberation" (see Mehdid on Algeria, 1996; Lievesley on Cuba, 2006), within the environmental movement, gender difference has been suppressed in the name of "greater humanity, community or class" (Salleh 1997: 6), or as the quote from the Portuguese ENGO suggest earlier, by "lack of time". Ruwanpura challenges the faith that "many, including feminists" have placed "in these [NGO] actors for creating a progressive space..." arguing that the NGOs "do not necessarily critically examine the neo-liberal agenda for its lack of attention to the nationalist and gender dynamics of local politics". This, she suggests, runs the risk of reinforcing "prevailing...gender dynamics" in that NGOs ignore the ways in which women from each community are marginalized. Indeed, in her conclusions, Ruwanpura suggests that to neglect the intersections of political strategy, power and feminism, "would be to inadvertently promote everyday forms of structural exclusion of women..." (Ruwanpura 2007:317). In an indirect appeal to intersectionality, Salleh invites the environmental justice movement to ask "where does the impact of class or race end, and gender effect begin." (p7). Although speaking with regard to Native people, Krall's assertion that "Even actions performed for the common good cannot be justified if they deny some the right to be", draws attention to the danger of the best motivated of campaigning activity ignoring the complexity of social marginalization (Krall 1994: 167).

This paper has observed a paucity of gender analysis in the literature on environmental in/justice, and a failure of many campaigns against environmental injustice to engage with their inherent gender injustices. From the evidence we have considered, it appears that gender considerations, and women's involvement in environmental justice, as often as not expressed as health campaigns, diminishes, the further removed these campaigns are from their grass roots. The scales at which these injustices are manifested are also important considerations. In terms of both impacts and campaigns, the body and 
the household are key, but often marginalized, sites of environmental injustice, while, in terms of campaigns, there is a distinct attenuation of women's presence the further from the grass roots one travels. The lack of women in organizations which arguably have the power to challenge environmental injustice at the national scale reinforces gender inequalities and limits the effectiveness of environmental justice. We argue that the "first environment" of the body (Sze, 2006) needs to be articulated much more explicitly as a site of environmental injustice and that the domestic division of labour constitutes a social injustice which is compounded by environmental considerations. The persistently unequal position of women, even in the technologically advantaged countries of North America and Europe, is both highlighted and reinforced by environmental problems. Unless the gender dimension of these problems is addressed in strategies put forward to overcome them, the social injustice of gender inequality, compounded with inequalities of race, ethnicity, poverty, age, will endure. We suggest that social relations within the household and in the workplace, as well as gender imbalances in influential posts in institutions and organizations which shape environmental justice discourse are likely, based on an analysis of gender and decision making, to have an impact on the decisions made (EHRC, 2008; Barsh et al, 2008). This imbalance, we further suggest, is compounded by an environmental sector whose staffing profiles closely mimic those in the governments and industries they lobby and campaign against. The impacts of such staffing patterns are under researched in environmental campaigning and decision making, and we suggest that this needs researching more closely (and see Kulcur, 2008).

For these reasons, we argue that a focus on either race/ethnicity or poverty, as delineations of environmental injustice, will not be sufficient to ensure that gendered injustices as a result of environmental problems are resolved. While there is vibrant women's involvement in grass roots environmental justice and health campaigning (Agyeman, 2005; Shrader-Frechette, 2002; Sze, 2004; 
Taylor, 1997, 2000), this paper has also revealed underfunding in the charitable sector exclusively focused on women (relative to non gender specific groups, or groups focused on animals, wildlife, buildings and so on). The examples we have drawn on, based on our field work, research projects and environmental activism, suggest that the ways in which organizations are structured indeed affect how they deal with both gender difference and environmental injustice. We would also argue that environmental justice can only be achieved if environmental and gender as well as other structures of injustice are identified and recognised at all scales. Oppression at all scales: from the body and household, through to the national and international, needs a better articulation and understanding within the organizations campaigning for environmental justice. For this, further analysis of the links between environmental injustices and gender oppression, and a commitment to gender equality is urgently needed.

\section{Acknowledgements}

With thanks to the Department of Resource Management and Geography at The University of Melbourne which hosted a period of research leave for Susan Buckingham, during which this paper was first written, and to Ariel Salleh who generously offered her time and critical comments on an early draft. Thanks also to the anonymous reviewers whose trenchant comments were valuable in strengthening the arguments of the paper.

\section{References}

Aguilar L (2009) Women and climate change: vulnerabilities and adaptive capacities in Worldwatch Institute 2009 State of the World. Into a Warming. (pp 59-62) World Washington: Worldwatch Institute Agyeman J (2000) Environmental Justice. From the Margins to the Mainstream London: Town and Country Planning Association 
Agyeman J (2005) Sustainable Communities and the Challenge of Environmental Justice New York: New York University Press

Agyeman J, Bullard R and Evans B (eds) (2003) Just Sustainabilities; Development in an Unequal World London: Earthscan

Bankwatch (2008) Bankwatch Overview http://www.bankwatch.org/about/ (last accessed on 23 February 2008)

Barsh J, Cranston S and Craske R (2008) Centered leadership: how talented women thrive. The McKinsey Quarterly, No 4

Birdlife International (2008) Staff http://www.birdlife.org/eu/eco_staff.html (last accessed 23 February 2008)

Bradshaw J, Finch N, Kemp P A, Mayhew E and Williams J (2003) Gender and Poverty in Britain. Manchester: Equal Opportunities Commission

Brenner N (2001) The limits to scale? Methodological reflections on scalar structuration. Progress in Human Geography 25; 591-614

Brulle R J and Essoka J (2005) Whose environmental justice? An analysis of the governance structure of environmental justice organisations in the United States. In Pellow N D and Brulle R J (eds) Power, Justice and the Environment, a Critical Appraisal of the Environmental Justice Movement. (pp 205-218) London: MIT Press

Buckingham S (2007) Microgeographies and microruptures. The politics of gender in the theory and practice of sustainability in Krueger R and Gibbs D (eds) The Sustainable Development Paradox; Urban Political Economy in the United States and Europe (pp66-94) New York: Guilford Buckingham S (2006) Environmental action as a space for developing women's citizenship in Buckingham S and Lievesley G (eds) In the Hands of Women: Paradigms of citizenship (pp62-94) Manchester: Manchester University Press 
Buckingham S, Reeves D and Batchelor A (2005) 'Wasting women: the environmental justice of including women in municipal waste management' Local Environment 10(4): 427-444

Bullard R D (1999) Dismantling environmental racism in the USA Local Environment, 4(1):5-20 Carter N (2001)The Politics of the Environment: Ideas, Activism, Policy. Cambridge: Cambridge University Press

Checker M (2005) Polluted Promises. Environmental Racism and the Search for Justice in a Southern Town. New York: New York University Press

Cheng C (1996) Masculinities in Organizations, Research on Men and Masculinities. London: Sage Climate Action Europe (2008) Climate Action Europe: Team and Contacts http://www.climnet.org/about/team.htm (last accessed 23 February 2008) Chopra K and Duraippah A K (2008) Operationalizing capabilities in a segmented society: the role of institutions, in Comim F, Qizilbash M and Alkire S (eds) The Capability Approach, Concepts, Measures and Applications. (pp362-382) Cambridge: Cambridge University Press Cuomo C (1994) Ecofeminism, deep ecology and human population. In Warren. K.J (ed) Ecological Feminism. (pp 88-105) London: Routledge

Di Chiro G (1998) Environmental justice from the grassroots: Reflections on history, gender and expertise. In Faber D R (ed) The struggle for environmental democracy: environmental justice movements in the United States (pp 104-136) New York: Guilford Press Directory of Social Change (2006) 'Majority say women do not control the voluntary sector' http://www.dsc.org.uk/charityexchange/news_archives/survey_results1006.html (last accessed 21 February 2008)

Dunnion K and Scandrett E (2003) in Agyeman J, Bullard R and Evans, B (eds) Just Sustainabilities. (pp311-322) London: Earthscan 
Environment Agency (2005) Life Cycle Assessment of Disposable and Reusable Nappies in the UK. Bristol: Environment Agency

Equality and Human Rights Commission (2008) Sex and Power 2008. London: EHRC European Commission (1999) Gender Mainstreaming 2/1999. Brussels: CEC

European Environmental Bureau (2008) Board http://www.eeb.org/board/Index.html (last accessed 23 February 2008)

European Federation for Transport and Environment (2008) Staff and board http://www.transportenvironment.org/module-htmlpages-display-pid-3.html (last accessed on 23 February 2008)

Fincher R (2006) 'Space, gender and institutions in processes creating difference' Gender, Place and Culture 14(1):5-27

Fouillet A, Rey G, Laurent F, Pavillon G, Bellec S, Guihenneuc-Jouvaux C, Clavel J, Jougla E and Hemon, D (2006) Excess mortality related to the August 2003 heat wave in France International Archives of Occupational and Environmental Health 80(1):16-24

Friends of the Earth Europe (2008) Contacts http://www.foeeurope.org/about/contact.htm (last accessed on 23 February 2008)

Friends of the Earth Europe (2008) Annual Review http://www.foeeurope.org/publications/2007/FoEE_annual_review2006.pdf (last accessed 20 February 2008)

Friends of Nature (2008) Board http://www.nfi.at/index.php?option=com_content\&task=view\&id=5\&ltemid=11 (last accessed 4 November 2008)

George G R (2007) Interpreting Gender Mainstreaming by NGOs in India: A comparative ethnographic approach Gender, Place and Culture 14,6: 679-701 
Gibbs L (1996) Love Canal: the Story Continues Gabriola Island, British Columbia: New Society Press Godfrey P (2006) Essentialism and the Semantics of Resistance: A Rejoinder to Jesse Goldstein.

Capital, Nature, Socialism. 17,4:103-104

Goldstein J (2006) Ecofeminism in Theory and Praxis Capital, Nature, Socialism. 17,4: 96-192

Greater London Authority (2004) Environmental Justice Report London: GLA

Greenpeace International (2008) Executive director

http://www.greenpeace.org/international/about/how-is-greenpeace-structured/management/executive-

director (last accessed 16 April 2009)

Greenpeace International (2008) International Board

http://www.greenpeace.org/international/about/how-is-greenpeace-structured/governance-

structure/board; (last accessed 16 April 2009)

Health and Environment Alliance (2008) Executive committee http://www.env-health.org/r/138 (last

accessed on 23 February 2008)

Hickman L (2005) It won't wash The Guardian 20 May

Johnsson-Latham G (2007) A study on gender equality as a prerequisite for sustainable development.

Stockholm: Environmental Advisory Council, Sweden

Krall F R (1994) Ecotone: wayfaring on the margins. SUNY Press: Albany, NY

Kurtz HE (2007) Gender and Environmental Justice in Louisiana: Blurring the boundaries of public and

private spheres. Gender, Place and Culture. 14,4: 409-426

Kulcur R (2008) "Gender and Environmental Movement" Paper presented at RGS-IBG Conference

Session Gender Matters: Postgraduate Reflections. London, UK, August

Lee J-A (2007) Gender, ethnicity, and hybrid forms of community-based urban activism in Vancouver, 1957-1978: The Strathcona story revisited Gender, Place and Culture 14,4:381-407 
London Sustainability Exchange (2004) Environmental Justice in London. Linking the Equalities and Environmental Policy Agendas. London: London Sustainability Exchange MacGregor S (2007) Beyond Mothering Earth. Ecological Citizenship and the Politics of Care. Vancouver: University of British Colombia Press

Marston S (2000) The Social Construction of Scale. Progress in Human Geography 24(2) 219-242 Marston S and Smith N (2001) States, scales and households: limits to scale thinking? A response to Brenner. Progress in Human Geography 25:615-619

McDowell L (1999) Gender, Identity and Place. Understanding Feminist Geographies Cambridge:

Polity

McDowell L (2004) Work, workfare, work/life balance and an ethic of care. Progress in Human

Geography 28,2: 145-163

Merchant C (2005, 2e) Radical Ecology. London: Routledge

Merchant C (1996) Earthcare: women and the environment. London: Routledge

Morrow K (2006) Gender, international law and the emergence of environmental citizenship in

Buckingham S and Lievesley G (eds) In the Hands of Women: Paradigms of citizenship (pp 33-61)

Manchester: Manchester University Press

Nightingale A (2006) The nature of gender: work, gender and environment. Environment and Planning D: Society and Space 24, 165-185

Pellow N D and Brulle R J (2005) Power, Justice, and the Environment. A critical appraisal of the environmental justice movement London/Cambridge, Mass: MIT Press

Physicians for Social Responsibility (2001) Environmental Endocrine Disruptors: what physicians should know http://www.psr.org/site/DocServer/Environmental_Endocrine_Disruptors.pdf?doclD=575 (last accessed 21 February 2008)

Plumwood V (1993) Feminism and the Mastery of Nature. London: Routledge 
Plumwood V (2002) Environmental Culture and the ecological crisis of reason. London: Routledge Pulido L (1996) Environmentalism and Economic Justice. Two Chicano Struggles in the Southwest.

Tucson: University of Arizona Press

Robeyns I (2008) Sen's capability approach and feminist concerns in Comim, F., Qizilbash, M and

Alkire S (eds) The Capability Approach, concepts, measures and applications (pp 82-104) Cambridge:

Cambridge University Press

Rooney C, McCmichael A J, Kmovats R S and Coleman M P (1998) Excess mortality in England and

Wales, and in Greater London, during the 1995 heatwave Journal of Epidemiology and Community

Health. 52(8): 482-486.

Ruwanpura K N (2007) 'Awareness and Action': The ethno-gender dynamics of Sri Lankan NGOs.

Gender, Place and Culture 14,3: 317-333

Salleh A (1997) Ecofemisnism as Politics: Nature, Marx and the Postmodern. Zed Books: London

Salleh A (2006) Embodying the deepest contradiction: a rejoinder to Alan Rudy. Capital, Nature,

Socialism 17,4:115-124

Salleh A (2008) Personal communication

Schlosberg D (2007) Defining Environmental Justice. Theories, Movements and Nature. Oxford: Oxford University Press

Schwarte C and Adebowale M (2007) Environmental Justice and Race Equality in the European Union. London: Capacity Global

Seager J (1993) Earth Follies; Coming to Terms With the Global Environmental Crisis. London:

Routledge

Sealy R and Singh V (2008) The importance of role models in the development of leaders' professional identity' in James K. \& Collins J. (eds) Leadership Learning: Knowledge into Action, Palgrave 
Sen A (2001) "Many Faces of Gender Inequality" Inauguration lecture presented to the Radcliffe Institute at Harvard University, April

Shakespeare T and Watson N (2002) The Social Model of Disability: an outdated ideology? Research in Social Science and Disability 2: 9-28

Shrader-Frechette K (2002) Environmental Justice, creating equality, reclaiming democracy. Oxford:

Oxford University Press

Smith N (1993) Uneven Development. Oxford: Blackwell

Sommestad L (2007) 'Women's Leadership for the Environment as a Human Right in Europe, Eastern

Europe and Beyond Keynote' Paper presented at WAVE conference in Belgrade, Serbia, October http://www.wecf.eu/cms/download/2007/Kenote_Address_Sommestad-WAVE_2007.pdf.

Staeheli L (1994) Empowering political struggle: spaces and scales of resistance. Political Geography 13: $387-391$

Sze J (2004) Gender, Asthma Politics, and Urban Environmental Justice Activism in Stein, R (ed) 2004 New Perspectives on Environmental Justice. Gender, Sexuality, and Activism. (pp 177-190) New Brunswick, New Jersey: Rutgers University Press

Sze J (2006) Boundaries and border wars: DES, technology, and environmental justice. American Quarterly 58(3) 791-814

Taylor D (1997) 'Women of color, environmental justice and ecofenminism' in Warren K (ed) Ecofeminism: Women, Culture and Nature (pp 38-81) Bloomington: Indiana University Press Taylor D (2000) The rise of the environmental justice paradigm: Injustice framing and the social construction of environmental discourses American Behavioural Scientist 43,4: 508-80 Turner T E and Brownhill L (2006) Ecofeminism as gendered, ethnicized class struggle: a rejoinder to Stuart Rosewarne. Capitalism Nature Socialism 17, 4: 87-95 
Turner T E and Brownhill L (2006) Ecofeminism as Gendered, Ethnicized Class Struggle: A Rejoinder to Stuart Rosewarne Capitalism Nature Socialism 17, 4: 87-95

United Nations (2005) Taking Action: achieving gender equality and empowering women. UN Millennium Project Task Force on Education and Gender Equality London: Earthscan United Nations Development Programme (2007) Fighting Climate Change. Human Solidarity in a changing world. New York: UNDP

Walker G, Mitchell G, Fairburn J and Smith G (2005) Industrial pollution and social deprivation: evidence and complexity in evaluating and responding to environmental inequality. Local Environment 10,4: $361-378$

Women's Environmental Network (2008) Environment Agency report reveals cloth nappies can save 40\% carbon emissions http://www.wen.org.uk/general_pages/Newsitems/pr_nappyreport17.10.08.htm (last accessed 4 November) 2008

Womens' Resource Centre (2006) Why Women? The women's voluntary and community sector: changing lives, changing communities, changing society. London: Women's Resource Centre World Bank (2002) Gender Mainstreaming Strategy Paper.

http://www.worldbank.org/gender/overview/ssp/home/htm. (last accessed 23 October 2006)

WWF (2008) About WWF http://www.worldwildlife.org/about/boardlist.cfm (last accessed on 23 February 2008)

WWF (2008) Board of trustees www.panda.org/about_wwf/where_we_work/europe/what_we_do/epo/about_us/about_people/index.cf m (last accessed on 16 April 2009) Young I M (1990) Justice and the Politics of Difference. Princeton: Princeton University Press 
1 The concept of race is used in US environmental justice campaigning, while in the UK, ethnicity is used.

2 While there is a substantial literature on global environmental injustices, and many environmental justice campaigns highlighting North/South injustices, this paper focuses on the environmental justice movement in the USA and Europe, and draws specifically on research conducted in Europe (primarily the UK).

${ }^{3}$ Robeyns uses Amartya Sen's 'capabilities approach', which focuses on the social, environmental and personal factors that enable people to convert goods and services into useful outcomes for themselves. It is predicated on an assumption of heterogeneity whereby each individual has a unique bundle of capabilities with which to effect this conversion. Importantly, this presupposes that it is capabilities such as education, health, social networks, respect from others in society and so on which determine how effectively goods and services can be used. While Sen's analysis primarily concerns people in the Global South, Robeyns applies this concept in 'affluent and technologically advanced economies' (2008: 83) to explore its specific utility in addressing feminist concerns.

${ }^{4} \mathrm{REACH}$ is the single integrated system for the 'registration, evaluation and authorization of chemicals' which the European Union has established.

${ }^{5}$ For example, the research underpinning the research presupposed that parents using cloth nappies would be using a washing machine dating from 19975; that families would use an average of 47 nappies per child (Guardian columnist, Leo Hickman suggests that this is more than double used in his family, (Hickman, 2007)); and that these nappies would only be used for one child, would be ironed (as Hickman wrote, incredulously 'who on earth irons their nappies?'), tumble dried and washed at 90 degrees $C$ (even though, as WEN points out, the reusable nappy manufacturers recommend $60 \mathrm{C}$ ). NB The Environment Agency published a revised analysis in October 2008 which is more equivocal concerning the comparable benefits of reusable and disposable nappies.

${ }^{6}$ Karen Morrow suggests that gender mainstreaming (GM) takes two forms: institutional and instrumental. In the former, GM is 'recognized as an integral part of the mainstream institutional agenda' and it is used to make institutional change; in the latter, 'gender-informed approaches are brought to bear on subject specific laws and policies and upon their implementation.' (2006:39) 